\title{
Information Technology on Economic Growth and Stability
}

\author{
T Handayani $^{1 *}$, R T Aprilia ${ }^{2}$, O Widaningsih ${ }^{3}$, F N Kesuma ${ }^{4}$, R Jumansyah ${ }^{5}$ \\ ${ }^{1}$ Management Department, Universitas Komputer Indonesia, Indonesia \\ ${ }^{2,3,4}$ Accounting Department, Universitas Komputer Indonesia, Indonesia \\ ${ }^{5}$ Information System Department, Universitas Komputer Indonesia, Indonesia \\ jumansyah.timkonferensiunikom@gmail.com
}

\begin{abstract}
This research aims to analyze how the role of information technology on economic growth and stability. Information technology at this time can be an important indicator of economic growth and stability. It is hoped that with information technology, a country can increase the production of goods and services. This research used descriptive qualitative in nature and with a literature review. The sample in this study is the growth and stability that occurs in various countries, especially Indonesia. This research discusses how information technology helps in increasing growth and stability in a country. The results of this study indicate that information technology is very influential on economic growth and stability. The role of information technology has the most influence on economic growth to increase the effectiveness of resource allocation in organizations by $85.2 \%$, and $77.8 \%$ of the response to information technology can increase the amount of investment in a company. The use of information technology will also speed up the production process by reducing the time needed to sort components and raw materials while reducing the potential for errors. It can be concluded that information technology is very influential in the economic growth rate of $96.3 \%$ of respondents.
\end{abstract}

Keywords: Information technology, Economic growth, Stability

\section{Introduction}

Globalization has led to many countries considering advancing technology, which has led to electronic finance becoming an important aspect in all economic and financial sectors (Hodrab \& Maitah, 2016). Economic growth is a very important indicator to identify and evaluate the development of a country, especially in the economic field. One of the main components that can affect economic growth, namely technological advances, is characterized by investment in new technologies that have the potential to improve a country's economy because new technology is definitely more efficient than old technology. In addition, technology is capable of creating goods, new capital, and producing high-quality goods with high economic value. The outcomes illustrate that ICT has a positive impact on the selected Arab countries' economic growth as well as the other factors except for inflation which has a negative impact on economic growth for these countries. The impact degree of ICT on economic growth is less than that of other countries especially emerging and developed economists (Alshubiri et al., 2019). The technology that is currently being developed rapidly in Information Technology. Information Technology is a technology for processing and distributing data using hardware and software. Information technology has become the main facility for various life sector activities.

There are several kinds of research regarding this topic. Nordhaus stated that it is feared that information technology will replace humans with machines (Nordhaus, 2015). However, this will never happen if the government in a country can improve the quality of human resources in order to adapt to jobs that have implemented sophisticated machine technology (Avgerou \& Walsham, 2017). Farhadi, Ismail, and Fooladi also said that information technology is a serious part of the economy that almost all companies use (Farhadi, 2012). Indeed, with the existence of company information technology can improve product quality and increase sales of goods and services, it is proven that economic growth in a country the more sophisticated technology, the faster the growth rate experienced by these countries (Deichmann, 2016). Khuong also said that embracing global trends proactively and seizing the opportunities emerging technology has enabled a country to achieve extraordinary economic performance 
(Vu, 2013; Schniederjans et al., 2010; Prasetyo, 2008; Yousefi, 2011; Gordon, 2012). Through the excellent use of technology and following the trends of the times, technology can make such a big change in Industrial Revolution 4.0. Both private and government-owned companies are competing, using increasingly sophisticated technology to support better operations and reduce other costs.

This research was conducted to analyze how the role of information technology on economic growth and stability. It is hoped that with this research we all understand that information technology is very important for the progress of a country. With information technology, the state can compete and develop rapidly because the state can increase the level of productivity. Data collection was carried out by distributing questionnaires to students and the public. To make information technology determinants of economic growth in a country, then use data from previous studies. Previous research is an attempt to find comparisons in a study, then to find new inspiration. Previous studies also help demonstrate the originality of a study.

\section{Method}

This research used qualitative descriptive research methods. We collect data on how big the role of information technology in economic growth. In the early stages of the research, a literature review was carried out to learn how to solve problems in the research methodology framework. To investigate the determinants of information technology on economic growth in a country, we refer to previous studies which have identified that the rate of economic growth is influenced by major. The factor is the accumulation of capital, population growth, and technological advances. The information and theory used are taken from scientific journals, sources from the internet, lecture teaching materials, library materials, and regulations related to this research.

\section{Results and Discussions}

\section{Information Technology Can Accelerate Economic Growth}

Technology, as one of the factors of economic growth, will have a turn to help improve the welfare of society (Balige, 2017) (see Figure 1).

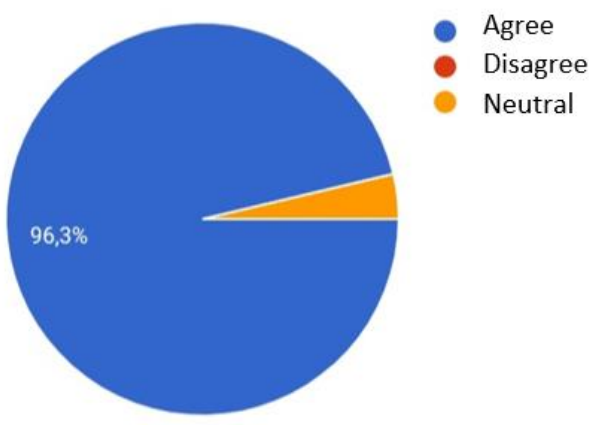

Figure 1. Results of Problem Test on Information Technology Can Accelerate Economic Growth

According to the results of the problem, technology can create economic efficiency and increase competitiveness. With lower input costs, the industry can produce goods quickly, in bulk, and with better quality. From the trade sector, technology has removed time and space limitations in buying and selling transactions. Literature in various fields shows that technology and innovation have improved the quality of human well-being. Technological change is inevitable and will continue to develop explosively. 
They added that artificial intelligence has the potential to replace human jobs. Through technology, various lines of human life move very fast. As a result, technological developments are always accompanied by a decline in sectors and actors who are unable to adapt. In the economic field, the application of technology and automation will have an impact on employment. This problem is not only faced by developing countries but also developed countries in the world. Therefore, the Minister of Finance also hopes that Indonesia must prepare steps to improve the quality of human resources, increase the labor market, and advance technology and innovation through research and development activities (Schniederjans, 2010).

\section{Information Technology Can Increase the Amount of a Country's Investment}

Based on the available data, most of the states that information technology can increase the amount of investment in a country. Therefore, nowadays, from individuals to the largest organizations, it should be encouraged to invest in information technology. Because investing in this field is a smart way that best meets all decision criteria (Schniederjans, 2010) (see Figure 2).

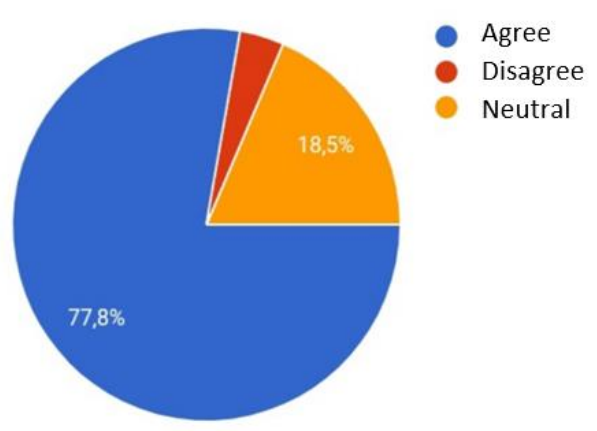

Figure 2. Results of Problem Test on Information Technology can increase investment

Currently, almost every financial sector has financial technological (fintech). In the field of capital markets, monetary technology can increase the number of investors quite a lot. This is due to financial and technological knowledge makes it easier for people who want to invest in the capital market. Fintech can reach all levels of society who want to become investors in the capital market. Digital foundations make fintech accessible from anywhere, including potential investors in remote areas. They can only invest in the capital market if they access financial technology services via a computer or smartphone. Not only investors who have large funds can invest in the capital market. But with ordinary capital, you can invest. Because currently, the capital market can be enjoyed and reached by all groups. It is estimated that 150 million people have become internet users today. Hence, this is seen as a potential for capital market deepening to develop rapidly and reach all society levels. Practical and easy to be the advantage of digital technology to be accepted by all generations of society. Especially the younger generation today who are reluctant to do something that takes up their time. This technology will be an option for those who don't have much time.

\section{Information Technology Can Improve the Efficiency of Resource Allocation}

Based on the data obtained, $85.2 \%$ stated that information technology could improve resource allocation efficiency. Information technology is an economic resource that can increase work efficiency and can increase productivity. The benefits of information technology can maximize, streamline all innovations and overall routine operational costs while still referring to approaches in measuring (measurement), conducting trials (experimentation), sharing (sharing), and replicating (replication) business processes (Prasetyo, 2008) (see Figure $3)$. 


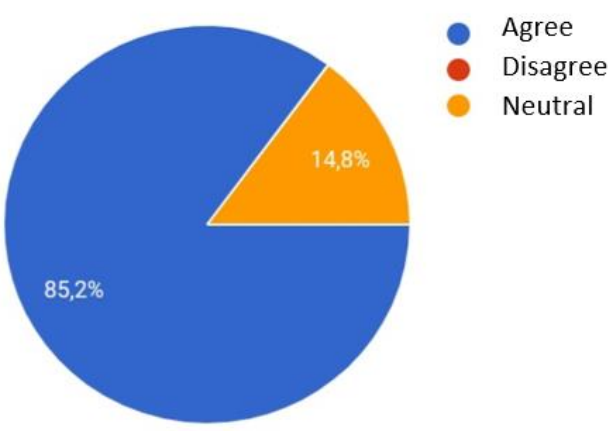

Figure 3. Results of Problem Test on Information Technology is Efficient

These four things have an important role for each other to increase the added value of information technology as a support and ease of organization. Diffusion of information technology substantially improves resource efficiency, greatly reduces production costs, and encourages demand and a much larger investment in all sectors of the economy (Yousefi, 2011). While the remaining $14.8 \%$ allows the organization not to use information technology optimally, the benefits of information technology will be hampered.

\section{Information Technology Can Reduce Production Costs}

From the data (See Figure 4), information technology can reduce production costs by about $15-20 \%$ of the factor. The use of robots and computers will speed up the production process in factories by reducing the time needed to sort components and raw materials while reducing the potential for errors. Information technology also plays a role in helping producers increase the categories of goods that can be produced. Computers provide the ability to manage various components with specifications that are almost the same as each other. Information technology affects the cost and quality of information and changes the economic value of information.

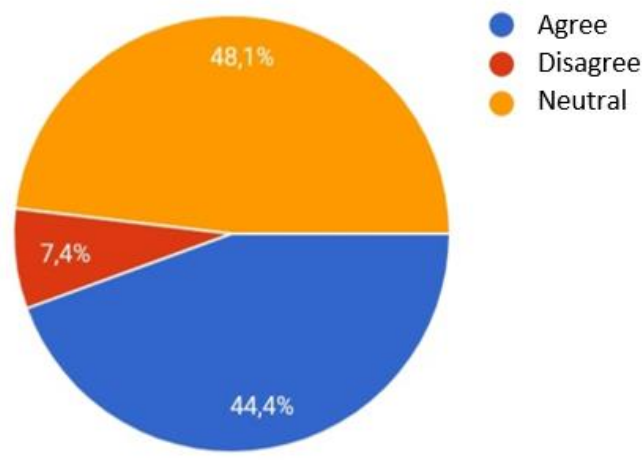

Figure 4. The Percentage Above Information Technology can Reduce Production Costs

Information technology helps companies get to counter with a fair value because information can reduce transaction costs imposed by companies that buy a market that cannot be produced. Information technology, especially the use of networks, can assist companies in the incidence of market cost costs (transaction costs), making contracts with suppliers more profitable using internal resources. With the cost of obtaining and analyzing information, it is possible to reduce agency costs because it facilitates managers in a larger number of employees (Indrayani, 2012). 
Based on the analysis of literature data and available qualitative data, our results show that information technology is indeed very important for the economy, especially the country's economy's growth and stability. Therefore, the existence of information technology in a country can increase the amount of productivity and reduce production costs. And with the existence of information technology, a country is expected to be able to carry out regular control in the process of implementing policies that have been made so that the objectives of these policies can be achieved in accordance with future plans to increase economic growth and stability and can increasingly compete with countries that have implemented information technology before because economic growth is a sustainable process that will last forever (Gordon, 2012).

In the last few decades, with the rapid development of technology. In the business world or at the level of small and medium enterprises to large companies, the use of technology is very important and dominant as a means of information communication and business operation. The era of globalization that removes boundaries has also led to the emergence of new industrial sectors that take advantage of technological developments' advantages to combine communication, information, and content (service entertainment) through computer networks. This causes economic movement from material exchange to exchange through technological media. With economic movements that occur indirectly, it can also contribute to economic growth. From a macro perspective, technological developments have stimulated economic development and contributed to economic growth.

\section{Conclusions and Recommendations}

From the above discussion, it can be concluded that information technology is very influential on the rate of economic growth of $96.3 \%$ of respondents. The role of information technology that has the most influence on economic growth is to increase the effectiveness of resource allocation in organizations by $85.2 \%$, and $77.8 \%$ of the response to information technology can increase the amount of investment in a company. The use of information technology will also speed up the production process by reducing the time needed to sort components and raw materials while reducing the potential for errors.

\section{Acknowledgments}

The authors thank the lecturers and supervisors who have provided insights and suggestions for this research. The author also has compassion for all parties involved in this research directly and indirectly.

\section{References}

Alshubiri, F., Jamil, S. A., \& Elheddad, M. (2019). The impact of ICT on financial development: Empirical evidence from the Gulf Cooperation Council countries. International Journal of Engineering Business Management, 11: 1847979019870670.

Avgerou, C., \& Walsham, G. (Eds.). (2017). Information technology in context: Studies from the perspective of developing countries. Routledge.

Balige B. 2017. Menkeu: Teknologi, Salah Satu Kunci Tingkatkan Ekonomi. Kemenkeu.go.id. https://www.kemenkeu.go.id/publikasi/berita/menkeu-teknologi-salah-satu-kuncitingkatkan-ekonomi/

Deichmann, U., Goyal, A., \& Mishra, D. (2016). Will digital technologies transform agriculture in developing countries?. The World Bank.

Farhadi, M., Ismail, R., \& Fooladi, M. (2012). Information and communication technology use and economic growth. PloS one, 7(11): e48903.

Gordon, R. J. (2012). Is US economic growth over? Faltering innovation confronts the six headwinds (No. w18315). National Bureau of Economic Research. 
Hodrab, R., \& Maitah, M. (2016). The effect of information and communication technology on economic growth: Arab world case. International Journal of Economics and Financial Issues, 6(2).

Indrayani, H. (2012). Penerapan Teknologi Informasi dalam Peningkatan Efektivitas, Efisiensi dan Produktivitas Perusahaan. Jurnal El-Riyasah, 3(1) : 48-56.

Nordhaus, W. D. (2015). Are we approaching an economic singularity? Information technology and the future of economic growth (No. w21547). National Bureau of Economic Research.

Prasetyo, P. E. (2008). The Quality of Growth: Peran Teknologi dan Investasi Human Capital sebagai Pemacu Pertumbuhan Ekonomi Berkualitas. JEJAK: Jurnal Ekonomi dan Kebijakan, 1(1).

Schniederjans, M. J., Hamaker, J. L., \& Schniederjans, A. M. (2010). Information technology investment: Decision-making methodology. World Scientific Publishing Company.

$\mathrm{Vu}$, K. M. (2013). Information and communication technology (ICT) and Singapore's economic growth. Information Economics and policy, 25(4): 284-300.

Yousefi, A. (2011). The impact of information and communication technology on economic growth: evidence from developed and developing countries. Economics of Innovation and New Technology, 20(6): 581-596. 